\title{
Okul Öncesi Öğretmenlerinin Müzik Etkinliklerinde Yaşadığı Sorunlar ${ }^{1}$
}

DOI NO: $10.5578 / J S S .7042$

Güneș Salı

Mümtaz Levent Akkol ${ }^{3}$

Vuslat Ŏguz ${ }^{4}$

\begin{abstract}
Özet
Bu araştırmada, okul öncesi ögrretmenlerinin müzik etkinliklerinde yaşadı̆̆ yaşadığı sorunların belirlenmesi amaçlanmıştır. Araştırmanın çalışma grubunu, Yozgat il merkezinde bulunan bağımsız anaokulları, kız meslek lisesi uygulama anaokulu ve ilkokul ana sinıflarında görev yapan toplam 62 ögretmen oluşturmaktadır. Okul öncesi öğretmenlerinin müzik etkinliklerinde karşılaştıkları sorunları belirlemek amacıyla, araştırmacılar tarafindan geliştirilen anket formu kullanılmıştır. Elde edilen veriler üzerinde, bir değişkene ait frekans dăgllımına ilişkin betimsel istatistikler kullanılmıştır. Araştırma sonucunda, okul öncesi ögretmenlerinin \%66.1'nin müzik alanındaki yeterlilik düzeyine ilişkin karşılaştığ sorunlar olduğu belirlenmiştir. Okul öncesi ögretmenlerinin \%33.9'unun müzik etkinliğinde çocukların yaratıcılıklarını destekleyen ortam sağlayabilme konusunda sorun yaşadığı bulunmuştur. Bu stray $\% 25.8$ oranla ilgi ve güdünün sürekliliğini sağlayabilmenin takip ettiği belirlenmiştir. Okul öncesi ögretmenleri, \%62.9'ar oranlarla sınıftaki müzik aletlerinin sayısının yetersiz olmasını ve okulda bir müzik odasının olmamasını müzik etkinliğini uygulamada sorun olarak gördüklerini belirtmişlerdir. \%56.5'i okul öncesi ögretmenlere yönelik okul öncesi eğitimde müzik ögretimi ile ilgili kurs/hizmet içi eğitim eksikliğini sorun olarak görmektedir.
\end{abstract} etkinlikleri

Anahtar Sözcükler: Okul öncesi eğitim, okul öncesi öğretmeni, müzik

1 Bu makale 31 Mayıs - 2 Haziran 2013 tarihleri arasında, Nevşehir'de düzenlenen "ULEAD 2013 Annual Congress: ICRE Multi-paradigmatic Transformative Research in Education: Challenges and Opportunuties, International Association of Educational Researchers" adlı kongrede sözlü bildiri olarak sunulmuştur.

2 Yrd.Doç.Dr., Bozok Üniversitesi, Eğitim Fakültesi, Eğitim Bilimleri Bölümü. gunes.sali@bozok.edu.tr

3 Öğretim Görevlisi, Bozok Üniversitesi, Eğitim Fakültesi, İlköğretim Bölümü. mumtazlevent@hotmail.com

4 Öğretim Görevlisi Dr., İnönü Üniversitesi, Sağlık Hizmetleri MYO, Çocuk Gelişimi Program1.vuslathope3@gmail.com 


\title{
Problems Experienced in Music Activities of Pre-School Teachers
}

\begin{abstract}
This research intended to identify the problems that the pre-school teachers live at musical activities. The working group of this research total composed of 62 teachers from private kindergartens, "Application Pre-school of Girls Professional High School" and pre-class teachers of primary schools at center of Yozgat province. A survey form which has developed by researchers is used to determine the problems experienced by pre-schoolteachers at music activities. On the obtained data frequency distribution for the variable statistics is used. As a result of the research, $66.1 \%$ of the preschool teachers have problems depends on their proficiency level of music. 33.9\%of the pre-school teachers have problems with observe environment to children which supports their creativity for music activities. The following result of the research in order, $25.8 \%$ of the pre-school teachers have problems with to ensure continuity and interest. $62.9 \%$ of the pre-school teachers told that in sufficiency of the musical instrument sand lack of a room for musical activities are also their problem for applying musical activities. $56.5 \%$, of the preschool teachers determines the lack of course and trainings on music teaching at pre-school educations a problem.
\end{abstract}

Key Words: Pre-school education, pre-school teacher, musical activities

\section{Giriș}

Okul öncesi eğitim çocukların doğumlarından temel eğitime başladığ1 zamana kadar geçen süreyi kapsayan, çocukların gelişim düzeylerine ve bireysel özelliklerine uygun, zengin uyarıcı çevre olanakları sağlayan, onların bedensel, zihinsel, duygusal ve sosyal yönden gelişimlerini destekleyen, kendilerini toplumun kültürel değerleri doğrultusunda en iyi biçimde yönlendirerek ilkokula hazırlayan, ileriki hayatlarında da önemli bir role sahip olan; psiko motor, sosyal duygusal ve bilişsel gelişimlerinin büyük ölçüde tamamlandığı ve kişiliklerinin şekillendiği, temel eğitimin ilk basamağıdır (Aral, Kandır ve Can Yaşar, 2002: 14; MEB, 2006: 3). Çocukluk yıllarında kazanılan davranışların büyük bir kısmı, yetişkinlikte bireyin kişilik yapısını biçimlendirmektedir (Yavuzer, 2000: 9). Kişiliğin temelinin atıldığ 1 kritik bir dönem olarak adlandırılan okul öncesi eğitimin, tüm eğitim basamaklarını, hatta bireyin tüm yaşamını etkilediği düşünüldüğünde, bu dönemde verilen eğitim daha da önem kazanmaktadır (Aral vd., 2002: 36).

Okul öncesi eğitim programlarında, okul öncesi eğitimin temel amaçlarının gerçekleşmesine yardım edecek pek çok etkinlik yer almaktadır. $\mathrm{Bu}$ etkinliklerden biri de müzik etkinlikleridir. Çocuğa, estetik duygularını geliştirecek biçimde temel müzik becerilerinin kazandırılması ve müziğin eğitsel araç olarak kullanımı, okul öncesi müzik etkinliklerinin amacını 
oluşturmaktadır (Aral vd., 2002: 126). Artan (1994: 103), okul öncesinde müzik etkinliklerinin gelişimsel amaçlarını; zihinsel gelişim ile ilgili amaçlar, fiziksel gelişim ile ilgili amaçlar, iletişim, farkında olma ve dil gelişimi ile ilgili amaçlar, yaratıcılık ve duygusal gelişim ile ilgili amaçlar biçiminde sıralamaktadır.

Zihinsel gelişim süreçleri arasında yer alan kavram gelişimi, müzik çalışmalarıyla kolayca kazandırılabilir (Artan, 1994: 30). Müzik, çocukların kavramları öğrenmelerini hızlandırmaktadır (Arslan, 1999: 142). Yapılan çalışmalar, erken yaşlardaki müzik eğitiminin çocukların kavram gelişimleri üzerinde etkili olduğunu göstermiştir (Bilhartz, Bruhn ve Olson, 1999: 618). Müzik etkinliklerinin tekrara olanak vermesi, sözcügüun, çocuk tarafından belleğe alınmasına olanak sağlamaktadır (Artan, 1994: 32). Overy, Norton, Cronin, Winner ve Schlaug (2005) tarafından müzik eğitiminin çocukların beyin ve bilişsel gelişimine olan etkisi incelenmiş, müzik eğitimi alan çocukların almayan çocuklara göre bilişsel becerilerinin geliştiği, akademik becerilerinin de arttığ saptanmıştır.

Çocuklara sunulan müzik ve hareket deneyimleri aynı zamanda, çocukların bedenlerini tanımalarını ve vücutlarının farkında olmalarını sağlamaktadır (Tselentis, 2000: 24). Müzik ve hareket deneyimleri, sinaptik bağlantılar kurulmasına yardımcı olmakta, nitelikli ve nicelikli duyu deneyimleri edinimini sağlamaktadır. Böylece beyin gelişimine katkıda bulunmaktadır. Çocuklara sunulan müzikli aktiviteler sayesinde, çocukların kan akışları hızlanmakta ve bu durum nöronlarla bağlantı kurulmasını sağlayarak kritik dönemde beyni beslemektedir (Tselentis, 2000: 22). Çocuğun dikkatini belli alanlarda yoğunlaştırabilme yeteneğinin gelişimine yardımcı olmakta, belleği güçlendirmektedir (Güngörmüş Özkardeş, 2005: 267). Bunun yanı sıra müzik dinlemek çocuğun akademik başarısını arttırmaktadır (Rauscher, 2003: 2). Müziksel zeka, melodi ve ritim tonlarını algılayabilme yeteneğini içermektedir. $\mathrm{Bu}$ yönleri ile dil gelişimini ve mantıksal- matematiksel zekayı beslemektedir. Örneğin: piyanoda tuşlara basarak bir melodiyi yaratma gibi deneyimlerle çocuk uygulama, analiz, sentez ve değerlendirme gibi yüksek düzeyde düşünme becerilerinin tamamını geliştirmektedir (Isenberg ve Jalongo, 1997: 131). Nitekim erken yaşlarda müzik çalgıları çalan çocukların bilişsel zeka seviyelerinin daha iyi olduğu görülmektedir. (Schlaug, Norton, Overy ve Winner, 2005: 224). Müzik dinlemenin, bilişsel testlerde öğrencinin başarısını arttırdığ1 da saptanmıştır (Schellenberg, 2005: 317).

Okul öncesi dönemde yapılan müzik etkinliklerinde çocuklar müzikle, bedensel hareketleri birleştirerek, müziğin karakterine ve ritmine uygun olarak belli bir düzen ve estetik içerisinde hareket etme becerisini kazanmakta (Özal Göncü, 2002: 11), yaratıc1 dansla müziğe uyum sağlayarak, büyük kas kontrolü için pratik oluşturmaktadırlar (Isenberg ve 
Jalongo, 1997: 131). Müziğin içindeki tüm ritimlerle çocuklar yürümekte, zıplamakta, sıçramakta, koşmakta ve kaymaktadırlar. Böylece çocukların lokomotor gelişimleri desteklenmiş olmaktadır (Tselentis, 2000: 24). Çocuklar, çalgıları çalarken küçük kaslarını etkin biçimde kullanmakta (Hirsh, 2004: 207) ve el- göz koordinasyonu sağlayabilme becerilerini geliştirmektedirler (Göncü, 2002: 11). Bunun yanı sıra, çocukta denge ve dikkat gelişimi de desteklenmektedir (Ersoy, 2003: 59). Bir çalg1 çalma ya da müzik eşliğinde hareket etme, çocuğun motor gelişimini olumlu yönde etkilemektedir (Özkardeş, 2005: 267).

Müzikal etkinlikler çocuğun dil gelişimine en iyi biçimde ortam sunmakta (Arslan, 1999: 142), dilin kurallarına uygun olarak kullanımını desteklenmektedir (Poyraz, 1998: 28). Müzikal etkinlikler, çocukların disiplin, uyum, rahatlama yeteneği, özgüven, sorumluluk, kişisel düşünce gibi kişilik özelliklerinin gelişiminde de etkili olmakta ve çocuğun yaşamdan aldığ1 zevki arttırmaktadır (Eskioğlu, 2005: 21). Birlikte müzik yapmak, çocuklara büyük keyif vermekte, bu ortamı yaşama firsatı bulan çocuklar, paylaşma duygusunun tadına vararak önemli bir sosyal beceri kazanmaktadırlar. Okul öncesi eğitim kurumlarında müziğe grup etkinlikleri kapsamında yer verilmesi, dolayısıyla birlikte müzik yapma, birlikte şarkı söyleme ortamları çocuklara liderlik yapma, izleme, taklit etme becerilerini kazanma olanağı sunarak onların sosyal gelișimlerini desteklemektedir (Artan, 1994: 108-109). Öte yandan, çocuk, okul öncesi müzik etkinlikleri içinde toplu şarkılar yoluyla kendini tanımakta; sınırlarını, yeteneklerini, yapabildiklerini ve yapamadıklarını fark etmekte, ayrıca grupla hareket etme yetisi kazanmaktadır (Erkunt, 2000: 31).

Müzik etkinlikleri, çocuğun duygusal gelişim alanında da olumlu izler bırakan, çocukların gelişimini olumlu etkileyen etkin bir eğitim aracıdır (Artan, 2003: 275). Okul öncesi dönemde müzik çalışmaları, çocukların içinde bulunmaktan mutlu oldukları etkinlik türüdür. Müziğin çocukların duygularını düzene sokan etkisi ve temel olarak çocuğun mutlu olduğu bir ortamda bulunması duygusal gelişimi bakımından katkılar içermektedir (Başer, 2004, http://web.archive.org/web/20070717194221/http://www .ef.sakarya.edu.tr/dergi/efdergisayi8.pdf). En doğal ve en etkin eğitim arac1 olan müzik yaşantıları yoluyla duygu ve düşüncelerini ifade etme firsatı bulan çocuğun duygu dünyası gelişir. Çalgıyla müzik yapma başta olmak üzere diğer etkinlik türleri, okul öncesi çocuğunun duygu dünyasına etki etmekte; güven duygusu ve disiplinli olma alışkanlığı kazanma, kendini tanıma, ulusal duyguları geliştirme, duyarlı olma gibi birçok olumlu etkiler yapmaktadır (Artan, 1994: 108-109). Okul öncesi müzik etkinlikleri, çocukların görsel uyarılara tepki yeteneğini de geliştirir, aynı zamanda, duyusal deneyimlerini kullanmasını sağlar. Duyusal deneyimleri kullanma 
sırasında çocukların tüm duyusal algıları ve duyuların gelişimi desteklenmektedir. (Mertoğlu, 1993: 252).

Okul öncesi dönem hem genel eğitimin hem de müzik eğitiminin ilk basamağıdır. Müziğin çocuk gelişimine getirdiği birçok katkılar nedeniyle okul öncesi dönemde, müzik etkinliklerinden doğru ve etkili biçimde yararlanmak gerekmektedir (Mertoğlu, 1993: 256). Okul öncesi eğitimde, nitelikli bir müzik etkinliğinin hazırlanması ve uygulanması, öğretmenin çocukların gelişim özelliklerini, gereksinimlerini bilmesi, temel müzik bilgisine, becerilerine sahip olması ve diğer etkinliklerle bütünleştirilebilmesi ile yakından ilişkilidir (Mertoğlu, 2005: 281). Ayrıca okul öncesi müzik etkinliklerinin amacına ulaşabilmesi için birçok etkinlik çeşidinin (müzikli oyunlar, ses dinleme, ses üretme ve ses ayırt etme çalışmaları, ritm çalışmaları, nefes açma ve şarkı söyleme çalışmaları, müzikli hareket, dramatizasyon ve yaratıcı dans çalışmaları, müzikli öykü vb.) birlikte kullanılmas1 gerekmektedir (Artan, 1994: 112).

Okul öncesi yıllarının öğrenme açısından ne kadar kritik ve önemli olduğu, yaşamın diğer dönemlerine oranla ne kadar hızlı öğrenildiği bilinmektedir. Okul öncesi dönemde müzik eğitimi, eğitimcilerin en önemli sorumluluklarından birisidir. Bu nedenle, müzik okul öncesi eğitiminin bir parçası olmalıdır. Burada eğitimci planlama, uygulama ve çalışma düzeni açısından önemli bir rol üstlenmektedir (Artan ve Bal, 1993: 235). Okul öncesi eğitimde müzik etkinliğini uygulayacak olan eğitimci, müzik etkinlikleri ile kazandırılacak amaç ve kazanımları belirlemeli, belirlediği amaç ve kazanımlara uygun müzik etkinliklerini planlayabilmelidir (Temiz, 2006: 197).

Çocukların ilk müziksel yaşantılarını kazandıkları okul öncesi kurumlarında müziği çocuklara sevdirecek, yeteneklerini keşfedecek olan öğretmenlerin müziksel donanımları çok önemlidir. Ancak, okul öncesi eğitim kurumlarında müzik etkinliklerinin istenilen bir biçimde gerçekleştirilmesi, okul öncesi öğretmenlerinin müzik etkinlikleri konusunda yeterli donanıma, bilgi ve becerilere sahip olmasının yanı sıra, öğretmen dışında sınıf ortamı, araç gereç, yöneticilerin yaklaşımı vb gibi başka birçok etkenle de yakından ilişkilidir. $\mathrm{Bu}$ açıdan, okul öncesi eğitim öğretmenlerinin, müzik etkinliklerini nasıl planladıklarını, nasıl uyguladıklarını ve nasıl değerlendirdiklerini ve tüm bunları gerçekleştirirken ne tür sorunlarla karşılaştıklarını bilmenin önemli olduğu düşünülmektedir.

Literatür incelendiğinde, anaokulu öğretmenlerinin okul öncesi dönemde müzik eğitimine ilişkin görüşleri (Mentiş Köksoy ve Mentiş Taş, 2005), okul öncesi öğretmenlerinin müzik eğitimi konusundaki görüşleri ve kendilerine ait değerlendirmeleri (Sı̆̆ırtmaç Dikici, 2006), okul öncesi öğretmenlerin müzik etkinliklerini gerçekleştirme durumları ve eğitim gereksinimleri (Güler, 2006), anasınıflarında görev yapan öğretmenlerin 
müzik eğitiminde yaşadıkları sorunları (Dere, 2008) inceleyen araştırmaların olduğu görülmektedir. Müziğin çocuk gelişimine birçok katkılar sağlaması nedeniyle okul öncesi eğitimde uygulanan müzik etkinliklerinde öğretmenlerin yaşadığı sorunların en aza indirgenmesi gerekliliğine karşın, bu sorunları inceleyen araştırmaların sınırlı sayıda olduğu görülmektedir. $\mathrm{Bu}$ nedenle bu araştırmada, okul öncesi öğretmenlerinin müzik etkinliklerinde yaşadığı sorunların belirlenmesi amaçlanmıştır.

\section{Yöntem}

Yozgat ili merkezinde bulunan bağımsız anaokullarında, ilkokullara bağlı anasınıflarında ve kı meslek lisesi uygulama anaokulundaki okul öncesi öğretmenlerinin, okul öncesi eğitimde uygulanan müzik etkinliklerinde yaşadıkları sorunları belirlemeyi amaçlayan bu çalışma betimsel bir araştırmadır.

Çalışma Grubu: Yozgat il merkezinde bulunan Milli Eğitim Bakanlığı'na bağlı bağımsız anaokullarında (22), ilkokula bağlı anasınıflarında (37) ve kız meslek lisesi uygulama anaokulunda (3) olmak üzere toplam 88 okul öncesi öğretmeni arasından araştırmaya gönüllü olarak katılan 62 okul öncesi öğretmeni bu araştırmanın çalışma grubunu oluşturmaktadır.

Veri Toplama Aracı: Araştırmada, okul öncesi öğretmenleri ile ilgili kişisel bilgileri elde etmek ve okul öncesi öğretmenlerin okul öncesi eğitimde uygulanan müzik etkinliklerinde karşılaştıkları sorunları belirlemek amacıyla araştırmacılar tarafından geliştirilen ve iki bölümden oluşan anket formu kullanılmıştır.

Anket formunda yer alan sorular oluşturulmadan önce okul öncesi öğretmenlerle yüz yüze görüşülmüş ve müzik etkinliklerinde yaşanılan sorunlar ile ilgili görüşleri not edilmiştir. Okul öncesi öğretmenlerin görüşlerinden yararlanarak araştırmacılar tarafindan anket formunun soruları oluşturulmuştur. Anket formu için öncelikle pilot çalışma yapılmıştır. $\mathrm{Bu}$ amaçla, öncelikle 20 kişilik bir okul öncesi öğretmen grubuna ön bir uygulama yapılmış ve öğretmenlerden alınan geri dönütler çerçevesinde anket soruları yeniden düzenlenerek son şekli verilmiştir.

"Ön uygulama, anketin geçerlik ve güvenirliğinin gözleme dayalı verilerle sorgulandığı bir aşamadır. Anketin taslak formundaki problemleri belirlemede öneme sahip olan ve araştırmanın hedef kitlesiyle benzer özelliklere sahip bir grup üzerinde yapılacak ön uygulama, geçerli ve güvenilir sonuçlar elde etmek için çok önemli bir aşamadır" (Büyüköztürk, Çakmak, Akgün, Karadeniz ve Demirel, 2009: 136). Anketin kapsam geçerliğini belirlemek amaciyla anket formunda yer alan sorulara ilişkin olarak beş uzman görüşü alınmıştır. Bu uzmanların üçü çocuk gelişimi ve 
eğitimi alanında öğretim üyesi, ikisi müzik eğitimi alanında öğretim üyesidir. Beş uzman görüşüne sunulan anket formunda yer alan sorularda öneriler doğrultusunda düzeltmelere yapılmıştır. Anket formunda 9 soru bulunmaktadır. 9. soru üç bölümden oluşmaktadır.

İşlem: Veriler, araştırmacılar tarafından geliştirilen Anket Formu'nun Yozgat il merkezinde bulunan bağımsız anaokulları, ilkokula bağlı anasınıfları ve kız meslek lisesi uygulama anaokulundaki okul öncesi öğretmenlerine uygulanması ile elde edilmiştir. Uygulamalar yapılmadan önce araştırmacının amacı ve önemi hakkında öğretmenlere açıklamalar yapılmıştır. Öğretmenlerin uygun oldukları saatler belirlenerek, çalışmaya katılmaya gönüllü olan öğretmenlerin Anket Formu'nu doldurmalar1 sağlanmıştır. Uygulamalar 15-20 dakika sürmüştür.

Verilerin Analizi: Anket Formu kullanılarak yapılan bu araştırmaya ait verilerin analizinde, SPSS 16.0 (Statistical Package for Social Sciences) istatistik programı kullanılmıştır. Elde edilen veriler üzerinde, bir değişkene ait frekans dağılımına ilişkin betimsel istatistikler kullanılmıştır. Frekans dağılımı, bir ya da daha çok değişkene ait değerlerin ya da puanların dağılımına ait özelliklerini betimlemek amaciyla verileri sayı ve yüzde olarak verir (Büyüköztürk, 2010).

\section{Bulgular ve Tartışma}

Okul öncesi eğitimde uygulanan müzik etkinliklerinde öğretmenlerin karşılaştıkları sorunları belirlemek amacıyla yapılan bu araştırmanın bulgularına ve bulgulara ilişkin tartışmalara aşağıda yer verilmiştir.

Tablo 1. Okul Öncesi Öğretmenlerinin "Müzik Alanındaki Yeterlilik Düzeyinize İlişkkin Karşılaştı̆̆ınız Sorunlar Var mı?" Sorusuna İlişkin Dağılımları

\begin{tabular}{|l|c|c|}
\hline $\begin{array}{l}\text { Müzik Alanındaki Yeterlilik Düzeyinize } \\
\text { İlişkin Karşılaştığınız Sorunlar Var mı? }\end{array}$ & $\mathbf{N}$ & $\mathbf{\%}$ \\
\hline Evet & 41 & 66.1 \\
\hline Hayır & 21 & 33.9 \\
\hline Toplam & $\mathbf{6 2}$ & $\mathbf{1 0 0 . 0}$ \\
\hline
\end{tabular}

Tablo 1 incelendiğinde, okul öncesi öğretmenlerinin \%66.1'nin müzik alanındaki yeterlilik düzeyine ilişkin karşılaştı̆g 1 sorunlar olduğu görülmektedir. Okul öncesi öğretmenlerinin \%33.1'i müzik alanındaki yeterlilik düzeyine ilişkin sorun yaşamadığını belirtmiştir. Yapılan başka araştırmalarda da benzer sonuçların elde edildiği görülmektedir. Dere'nin (2008) yaptığı araștırmaya göre, okul öncesi öğretmenlerin yalnızca \%22.1'i kendisini müzik alanında yeterli bulduğunu ifade etmiş̧tir. Aynı çalışmada, 
okul öncesi öğretmenlerin \%12.74'ü kendisini yeterli bulmadığını belirtirken, \%66.4'ü kendisini orta düzeyde yeterli bulduğunu ifade etmiştir.

$\mathrm{Bu}$ bulgular, zaman ilerledikçe yani 2009'dan 2013'e gelindiğinde müzik alanındaki yeterlilik düzeyine ilişkin sorun yaşayan okul öncesi öğretmenlerin oranında artış olduğu şeklinde değerlendirilebilir.

Tablo 2. Okul Öncesi Öğretmenlerinin "Müzik Alanındaki Yeterlilik Düzeyinize İlişkin Karşılaştı̆̆ınız Sorunların Kaynağı Olarak Neyi/Neleri Görüyorsunuz?” Sorusuna İlişkin Dă̆ılımları

\begin{tabular}{|l|c|c|}
\hline $\begin{array}{l}\text { Müzik Alanındaki Yeterlilik Düzeyinize } \\
\text { İlişkin Karșılaştığınız Sorunların Kaynağı } \\
\text { Olarak Neyi/Neleri Görüyorsunuz? }\end{array}$ & N & \% \\
\hline Enstrüman kullanmayı bilmiyorum & 21 & 33.9 \\
\hline $\begin{array}{l}\text { Herhangi bir hizmet içi eğitimde müzik eğitimi } \\
\text { almadım }\end{array}$ & 18 & 29.0 \\
\hline $\begin{array}{l}\text { Lisans eğitimimde notalı şarkı söyleme, bir } \\
\text { müzik aleti çalma yeteneği kazandırılmadı }\end{array}$ & 15 & 24.2 \\
\hline Şarkı dağarcığım yeterli değil & 5 & 8.1 \\
\hline Temel eğitimden kaynaklanan eksiklikler & 5 & 8.1 \\
\hline $\begin{array}{l}\text { Lisans eğitimim süresince müzik eğitimi } \\
\text { almadım }\end{array}$ & 4 & 6.5 \\
\hline Müziğe karşı ilgim yok & 3 & 4.8 \\
\hline
\end{tabular}

Okul öncesi öğretmenlerinin müzik alanındaki yeterlilik düzeyine ilișkin karşılaştığ1 sorunların kaynağı olarak \%33.9'u enstrüman kullanmayı bilmediğini; \%29.0'u herhangi bir hizmet içi eğitimde müzik eğitimi almamasını; \%24.2'si lisans eğitiminde notalı şarkı söyleme, bir müzik aleti çalma yeteneğinin kazandırılmamasını; \%8.1'i şarkı dağarcığının yeterli olmamasını; \%8.1'i temel eğitimden kaynaklanan eksiklikler olduğunu; $\% 6.5$ 'i lisans eğitimi süresince müzik eğitimi almamasını; \%4.8'i ise müziğe karşı ilgisinin olmamasını neden olarak gördüğünü ifade etmiştir. Araştırmaya katılan öğretmenlerin müzik alanındaki yeterlilik sorunlarına ilişkin en önemli kaynak öğretmenin enstrüman kullanmayı bilmemesi olarak belirlenmiştir. Elde edilen bu sonuç, okul öncesi dönemde müzik eğitimi vermenin okul öncesi öğretmenlerinin bir enstrümanı çalma ile ilişkilendirdiğini düşündürmektedir. Yapılan bir araştırmada da (Dere, 2008: 48) öğretmenlerin \%58.96'sının enstrüman çalmadığı belirlenmiştir. 
Tablo 3. Okul Öncesi Öğretmenlerinin "Okul Öncesi Dönemde Müzik Etkinliği Uygulamaları İle İlgili Kişisel Gelişiminize Katkıda Bulunmak Iç̧in Çaba Harcıyor musunuz?" Sorusuna İlişkin Dağılımları

\begin{tabular}{|l|c|c|}
\hline $\begin{array}{l}\text { Okul Öncesi Dönemde Müzik Etkinliği } \\
\text { Uygulamaları İle İlgili Kişisel Gelişiminize }\end{array}$ & N & \% \\
$\begin{array}{l}\text { Katkıda Bulunmak İçin Çaba Harcıyor } \\
\text { musunuz? }\end{array}$ & & \\
\hline Evet & 36 & 58.1 \\
\hline Hayır & 19 & 30.6 \\
\hline Görüş bildirmeyenler & 7 & 11.3 \\
\hline Toplam & $\mathbf{6 2}$ & $\mathbf{1 0 0 . 0}$ \\
\hline
\end{tabular}

Okul öncesi öğretmenlerinin \%58.1'inin okul öncesi dönemde müzik etkinliği uygulamaları ile ilgili kişisel gelişimine katkıda bulunmak için çaba harcadığ1 belirlenmiştir. \%30.6's1 ise, bu konuda çaba harcamadığını belirtmiştir. Okul öncesi öğretmenlerinin \%11.3'ü okul öncesi dönemde müzik etkinliği uygulamaları ile ilgili kişisel gelişimine katkıda bulunup bulunmama konusunda görüş bildirmemiştir. Okul öncesi dönemde öğretmenlerin müzik eğitimi vermeyi bir enstrüman çalma ile ilişkilendirmeleri ve öğretmenlerin kişisel gelişimlerine katkıda bulunmak için \%58.1'inin çaba sarf etmesi düşündürücü bir sonuç olarak değerlendirilebilir.

Tablo 4. Okul Öncesi Öğretmenlerinin "Müzik Etkinliğini Başka Etkinliklerle Bütünleştiriyor musunuz? ” Sorusuna İlişkin Dağılımları

\begin{tabular}{|l|c|c|}
\hline $\begin{array}{l}\text { Müzik Etkinliğini Başka Etkinliklerle } \\
\text { Bütünleştiriyor musunuz? }\end{array}$ & N & \% \\
\hline Evet & 54 & 87.1 \\
\hline Hayır & 4 & 6.5 \\
\hline Görüş bildirmeyenler & 4 & 6.5 \\
\hline Toplam & $\mathbf{6 2}$ & $\mathbf{1 0 0 . 0}$ \\
\hline
\end{tabular}

Tablo 4'te okul öncesi öğretmenlerinin \%87.1'inin müzik etkinliğini başka etkinliklerle bütünleştirdiği görülmektedir. Öğretmenlerin $\% 6.5$ 'i müzik etkinliğini başka etkinliklerle bütünleştirmediğini belirtirken, $\% 6.5$ 'i görüş bildirmemiştir. Öztürk’e (2007) göre, müzik okul öncesi eğitimde tüm etkinliklerde yer almalıdır. Buna göre, araştırmaya katılan öğretmenlerin büyük bir çoğunluğunun diğer etkinlikleri uygularken müzik etkinliğine yer vermeye önem verdikleri söylenebilir. 
Tablo 5. Okul Öncesi Öğretmenlerinin "Müzik etkinliğini diğer etkinliklerle bütünleştirirken sorun yaşıyorsanız hangisi / hangileri ile bütünleştirirken sorunla karşılaşıyorsunuz? ” Sorusuna İlişkin Dağılımları

\begin{tabular}{|l|c|c|}
\hline $\begin{array}{l}\text { Müzik etkinliğini diğer etkinliklerle } \\
\text { büiünleștirirken sorun yaşıyorsanız hangisi } \\
\text { /hangileri ile bütünleştirirken sorunla } \\
\text { karşılaşıorsunuz? }\end{array}$ & N & \% \\
\hline Drama Etkinliği & 10 & 16.1 \\
\hline Fen Etkinliği & 10 & 16.1 \\
\hline Oyun Etkinliği & 9 & 14.5 \\
\hline Okuma Yazmaya Hazırlık Çalışmaları & 8 & 12.9 \\
\hline Matematik Etkinliği & 6 & 9.7 \\
\hline Türkçe Etkinliği & 5 & 8.1 \\
\hline Alan Gezileri & 4 & 6.5 \\
\hline Fen-Matematik Etkinliği & 4 & 6.5 \\
\hline Sanat Etkinliği & 4 & 6.5 \\
\hline Hareket Etkinliği & 2 & 3.2 \\
\hline Serbest zaman etkinliği-ilgi köşeleri & 2 & 3.2 \\
\hline
\end{tabular}

Tablo 5 incelendiğinde, okul öncesi öğretmenlerinin müzik etkinliğini drama etkinliği ve fen etkinliği ile bütünleştirirken \%16.1'er oranlarda sorunla karșılaștıkları görülmektedir. Öğretmenlerin \%14.5'i oyun etkinliğini; \%12.9'u okuma yazmaya hazırlık çalışmalarını; \%9.7'si matematik etkinliğini; \%8.1'i Türkçe etkinliğini, \%6.5'er oranlarda alan gezilerini, fen-matematik etkinliğini ve sanat etkinliğini; \%3.2'şer oranlarda hareket etkinliği ile serbest zaman etkinliği-ilgi köșelerini; müzik etkinliğini bütünleştirmede sorun olarak göstermişlerdir. Okul öncesi dönemde müzik etkinliğini, drama etkinliği ve fen etkinliği ile bütünleştirmede okul öncesi öğretmenlerinin sorunla karşılaşması, öğretmenin her iki etkinliği de müzik etkinliği ile bütünleştirmede planlarken ve uygularken yaşadığ eksiklikler olarak değerlendirilebilir. Serbest zaman etkinliği ve hareket etkinliği içeriği gereği, müzik etkinliği uygulamalarının daha kolay bütünleştirilebildiği etkinliklerdir. $\mathrm{Bu}$ nedenle, öğretmenler serbest zaman ve hareket etkinliğini müzik etkinliğini ile bütünleştirirken daha az sorun yaşıyor olabilirler. Ayvacı, Devecioğlu ve Yiğit (2002) tarafından yapılan bir araştırmada okul öncesi öğretmenlerinin çoğunun fen ve doğa etkinliklerini istenen nitelikte planlama ve yürütme becerisine sahip olmadıkları, orijinal materyal geliştirmedikleri ve etkinlikleri uygularken kullanılacak etkili öğretim yöntemlerinden (soru-cevap, gösterip yaptırma vb. dışındaki diğer tekniklerden; oyun ve drama vb.) haberdar olmadıkları ve kullanmadıkları belirlenmiştir. Okul öncesi öğretmeninin müzik etkinliğini başka bir etkinlik ile bütünleştirirken hem müzik etkinliğinde hem de diğer etkinliklerde yeterli olması beklenir. Okul öncesi öğretmeninin fen ya da drama etkinliğinde 
yeterli olmayış1 da müzik etkinliği ile bütünleştirme okul öncesi öğretmeninin sorun yaşamasına neden olmuş olabilir.

Tablo 6. Okul Öncesi Öğretmenlerinin "Müzik Etkinliğinde Aile Katılımı Çalışmalarına Yer Veriyor musunuz?” Sorusuna İlişkin Dağılımları

\begin{tabular}{|l|c|c|}
\hline $\begin{array}{l}\text { Müzik Etkinliğinde Aile Katılımı } \\
\text { Çalışmalarına Yer Veriyor musunuz? }\end{array}$ & $\mathbf{N}$ & $\mathbf{\%}$ \\
\hline Evet & 29 & 46.8 \\
\hline Hayır & 32 & 51.6 \\
\hline Görüş bildirmeyenler & 1 & 1.6 \\
\hline Toplam & $\mathbf{6 2}$ & $\mathbf{1 0 0 . 0}$ \\
\hline
\end{tabular}

Müzik etkinliğinde aile katılım çalıșmalarına yer verme açısından okul öncesi öğretmenlerinin \%46.8'inin aile katılım çalışmalarına yer verdiği, \%51.6'sının müzik etkinliğinde aile katılım çalışmalarına yer vermediği, \%1.6'sının ise bu konuda görüş bildirmediği belirlenmiștir. Okul öncesi dönemde, müzik eğitimi de dahil olmak üzere aile katılımı çalışmalarına yer vermek çocuğun eğitimi açısından çok önem taşımaktadır. Ancak, bu araştırmada okul öncesi öğretmenlerinin müzik eğitiminde yalnızca \%46.8'inin aile katılımı çalışmalarına yer verdiği sonucuna ulaşılmıştır.

Tablo 7. Okul Öncesi Öğretmenlerinin "Müzik Etkinliğinde Aile Katılımı Çalışmalarında Ne Tür Sorunlarla Karşılaşıyorsunuz?” Sorusuna İlişkin Dağglımlart

\begin{tabular}{|l|c|c|}
\hline $\begin{array}{l}\text { Müzik Etkinliğinde Aile Katılımı Çalışmalarında } \\
\text { Ne Tür Sorunlarla Karşılaşıyorsunuz? }\end{array}$ & N & \% \\
\hline $\begin{array}{l}\text { Müzik etkinliği uygulamalarını evde çocukla birlikte } \\
\text { aileleri ile uygulamaları konusunda }\end{array}$ & 21 & 33.9 \\
\hline $\begin{array}{l}\text { Müzik etkinliğine ailelerin çocuklarla birlikte okulda } \\
\text { katılmaları konusunda }\end{array}$ & 8 & 12.9 \\
\hline $\begin{array}{l}\text { Müzik etkinliği uygulamalarında ailelerin bana } \\
\text { yardımcı olmaları konusunda }\end{array}$ & 2 & 3.2 \\
\hline
\end{tabular}

Tablo 7'de görüldüğü gibi, müzik etkinliğinde aile katılım çalışmalarında okul öncesi öğretmenlerinin \%33.9'u müzik etkinliği uygulamalarını evde çocukla birlikte aileleri ile uygulamaları konusunda; \%12.9'u müzik etkinliğine ailelerin çocuklarla birlikte okulda katılmaları konusunda; \%3.2'si ise müzik etkinliği uygulamalarında ailelerin öğretmene yardımcı olması konusunda sorunla karşılaşmaktadır. Müzik etkinliğini uygulamalarını evde çocukla birlikte aileleri ile uygulamaları konusunda okul öncesi öğretmenlerinin \%33.9'unun sorun yaşıyor olmasının nedeni ailelerin müzik eğitimine önem vermiyor olması olabilir. Ayrıca, Tablo 1 
incelendiğinde, okul öncesi öğretmenlerinin \%66.1'inin müzik alanındaki yeterlilik düzeyine ilişkin karşılaştığı sorunlar olduğu görülmektedir. Aileler de evde çocukları ile müzik eğitimi uygulamaları konusunda kendilerini yeterli bulmuyor olabilirler.

Tablo 8. Okul Öncesi Öğretmenlerinin “Müzik Etkinliği Uygulamalarınıza İlişkin Olarak Sınıf Yönetimi Konusunda Karşılaştığınız Sorunlar Nelerdir?” Sorusuna İlişkin Dağılımları

\begin{tabular}{|l|c|c|}
\hline $\begin{array}{l}\text { Müzik Etkinliği Uygulamalarınıza İlişkin } \\
\text { Olarak Sınıf Yönetimi Konusunda } \\
\text { Karşılaştığınız Sorunlar Nelerdir? }\end{array}$ & N & \% \\
\hline $\begin{array}{l}\text { Müzik etkinliğinde çocukların yaratıcılıklarını } \\
\text { destekleyen ortam sağlayabilme }\end{array}$ & 21 & 33.9 \\
\hline $\begin{array}{l}\text { Müzik etkinliğinde ilgi ve güdünün sürekliliğini } \\
\text { sağlayabilme }\end{array}$ & 16 & 25.8 \\
\hline $\begin{array}{l}\text { Müzik etkinliğinde kesinti ve engellemelere karşı } \\
\text { uygun önlemler alabilme }\end{array}$ & 9 & 14.5 \\
\hline $\begin{array}{l}\text { Müzik etkinliğinde sınıfı toplayabilme ve diğer } \\
\text { etkinliğe geçişte sınıfı düzenleyebilme }\end{array}$ & 6 & 9.7 \\
\hline Müzik etkinliğinde sınıfa hakim olabilme & 4 & 6.5 \\
\hline $\begin{array}{l}\text { Müzik etkinliğinde demokratik bir öğrenme } \\
\text { ortamı sağlayabilme }\end{array}$ & 3 & 4.8 \\
\hline Müzik etkinliğe uygun bir giriş yapabilme & 3 & 4.8 \\
\hline
\end{tabular}

Tablo 8'de okul öncesi öğretmenlerinin müzik etkinliği uygulamalarında sınıf yönetimi konusunda karşılaştığı sorunlar incelendiğinde, $\% 33.9$ oranla müzik etkinliğinde çocukların yaratıcılıklarını destekleyen ortam sağlayabilme ilk sırayı almaktadır. Bu sıray $\% 25.8$ oranla müzik etkinliğinde ilgi ve güdünün sürekliliğini sağlayabilme, $\% 14.5$ oranla müzik etkinliğinde kesinti ve engellemelere karşı uygun önlemler alabilme, \%9.7 oranla müzik etkinliğinde sınıfı toplayabilme ve diğer etkinliğe geçişte sınıfı düzenleyebilme, $\% 6.5$ oranla müzik etkinliğinde sınıfa hakim olabilme, $\% 4.8$ oranla müzik etkinliğinde demokratik bir öğrenme ortam1 sağlayabilme, \%4.8 oranla müzik etkinliğine uygun bir giriş yapabilme izlemektedir. Müzik etkinliği uygulamalarında öğretmenin yaratıcı olması çok önemlidir. Araştırmaya katılan öğretmenlerin kendi yaratıcılık düzeyi, müzik etkinliğinde çocukların yaratıcılıklarını destekleyen bir ortam sağlamasını etkiliyor olabilir. Araştırmada öğretmenler, sınıftaki müzik aletlerinin yetersiz olduğunu, okulda bir müzik odası bulunmadığını \%62.9'la yüksek bir oranda müzik etkinliğini uygulamada karşılaştıkları sorun olarak belirtmişlerdir. Yaratıcı ortam sağlanmasında müzik aletlerinin yetersiz oluşu ve ayrı bir müzik odasının da bulunmayışı, çocuklara müzik eğitiminde yaratıcı ortam yaratılmasını olumsuz etkilemiş olabilir. 
Tablo 9. Okul Öncesi Öğretmenlerinin “Aşağıdaki Seçenek/Seçeneklerden, Hangisi/Hangilerini Müzik Etkinliğinizi Uygulamada Sorun Olarak Görüyorsunuz?

(1. Bölüm)" Sorusuna İlişkin Dağılımları

\begin{tabular}{|c|c|c|}
\hline $\begin{array}{l}\text { Aşağıdaki Seçenek/Seçeneklerden } \\
\text { Hangisi/Hangilerini Müzik Etkinliğinizi Uygulamada } \\
\text { Sorun Olarak Görüyorsunuz? } \\
\text { (1. Bölüm) }\end{array}$ & $\mathbf{N}$ & $\%$ \\
\hline Sınıfımdaki müzik aletlerinin sayısı yetersiz. & 39 & 62.9 \\
\hline Okulumuzda bir müzik odası yok. & 39 & 62.9 \\
\hline $\begin{array}{l}\text { Okul öncesi öğretmenlere yönelik okul öncesi eğitimde } \\
\text { müzik öğretimi ile ilgili kurs/hizmet içi eğitim eksik. }\end{array}$ & 35 & 56.5 \\
\hline $\begin{array}{l}\text { Çocuklar ritim aletlerini kullanırken sürekli serbest } \\
\text { şekilde kullanmayı istiyorlar. }\end{array}$ & 32 & 51.6 \\
\hline Çocuklar aynı müzik aletini aynı anda istiyorlar. & 28 & 45.2 \\
\hline $\begin{array}{l}\text { Çocuklar ritim aletlerini kullanmayı bilmediklerinde } \\
\text { farklı ritim tutuyorlar, bu durum karmaşa yaşanmasına } \\
\text { neden oluyor. }\end{array}$ & 27 & 43.5 \\
\hline $\begin{array}{l}\text { Çocuklar ritim aletlerini kullanırken uyumsuz davranış } \\
\text { gösteriyorlar. }\end{array}$ & 26 & 41.9 \\
\hline Şarkı dinlemek için CD’miz yok. & 25 & 40.3 \\
\hline $\begin{array}{l}\text { Müzik etkinliği uygularken bazı çocuklar konuşuyor, } \\
\text { diğer çocukların dikkatlerini dağıtıyor, motivasyonlarını } \\
\text { düşürüyor. }\end{array}$ & 24 & 38.7 \\
\hline Okulda bir müzik öğretmeni yok. & 21 & 33.9 \\
\hline $\begin{array}{l}\text { Okul öncesi öğretmenliği lisans programlarında müzik } \\
\text { öğretimine yeterince yer verilmiyor. }\end{array}$ & 18 & 29.0 \\
\hline Bilgisayarımız yok. & 18 & 29.0 \\
\hline Sınıfta yardımcı bir öğretmen yok. & 17 & 27.4 \\
\hline $\begin{array}{l}\text { Çocuklar ritim aletlerini ritim duygusu içersinde } \\
\text { kullanmıyorlar. }\end{array}$ & 15 & 24.2 \\
\hline $\begin{array}{l}\text { Çok çeşitte ritim aleti kullanıldığında çocuklar ritim } \\
\text { tutmakta zorlanıyorlar. }\end{array}$ & 15 & 24.2 \\
\hline $\begin{array}{l}\text { Karşılaştığım şarkılarda nota, vurgu ve vuruşları } \\
\text { çıkaramıyorum. }\end{array}$ & 15 & 24.2 \\
\hline Çocuklar / çocukların bazıları özgüven eksikliği yaşıyor. & 14 & 22.6 \\
\hline $\begin{array}{l}\text { Sınıfımda çeşitli müzik etkinliklerini uygulamak için } \\
\text { alan yetersiz. }\end{array}$ & 13 & 21.0 \\
\hline Sınıfımda hiç müzik aleti yok & 12 & 19.4 \\
\hline Sınıfımda bir müzik köșesi yok. & 12 & 19.4 \\
\hline
\end{tabular}


Okul öncesi öğretmenleri, \%62.9'ar oranlarla sınıftaki müzik aletlerinin sayısının yetersiz olmasını ve okulda bir müzik odasının olmamasını müzik etkinliğini uygulamada sorun olarak gördüklerini belirtmişlerdir. \%56.5'i okul öncesi öğretmenlere yönelik okul öncesi eğitimde müzik öğretimi ile ilgili kurs/hizmet içi eğitim eksikliğini; \%51.6's1 çocukların ritim aletlerini kullanırken sürekli serbest şekilde kullanmayı istemelerini; \%45.2'si çocukların aynı müzik aletini aynı anda istemesini; \%43.5'i çocukların ritim aletlerini kullanmayı bilmediklerinde farklı ritim tutmalarını, bu durumun karmaşa yaşanmasına neden olmasını; \%41.9'u çocukların ritim aletlerini kullanırken uyumsuz davranış göstermesini; \%40.3'ü şarkı dinlemek için CD olmamasını; \%38.7'si müzik etkinliği uygularken bazı çocuklar konuşarak diğer çocukların dikkatini dağıtmasını ve çocukların motivasyonlarının düșmesini; \%33.9'u okulda bir müzik öğretmeni olmamasını; \%29'u okul öncesi öğretmenliği lisans programlarında müzik öğretimine yeterince yer verilmemesini; \%27.4'ü sinıfta yardımcı bir öğretmen bulunmamasını; \%24.2'şer oranlarla çocukların ritim aletlerini ritim duygusu içersinde kullanmamasını, çok çeşitte ritim aleti kullanıldığında çocukların ritim tutmakta zorlanmasını ve karşılaştığ1 şarkılarda nota, vurgu ve vuruşları çıkaramamasını; \%22.6'sı çocukların bazılarının özgüven eksikliği yaşamasını; \%21'i sınıfında çeşitli müzik etkinliklerini uygulamak için alanın yetersiz olmasını; \%19.4 oranlarda ise sınıfında hiç müzik aleti bulunmamasını ve sınıfında bir müzik köșesi olmamasını müzik etkinliğini uygulamada sorun olarak gördüğünü belirtmiştir.

Okul öncesi öğretmenleri müzik etkinliği uygulamalarında karşılaştıkları sorun olarak en yüksek oranlarda sınıflarındaki müzik aletlerinin yetersiz oluşunu ve okulda bir müzik aletinin bulunmamasını göstermişlerdir. Elde edilen bu bulgu ile araştırmaya katılan öğretmenlerin, müzik etkinliğini gerçekleştirebilecekleri bir alanın olmasını ve müzik aletlerinin yeterli olmasını müzik etkinliği uygulamalarının yapılabilmesi için daha çok önemsedikleri söylenebilir. Yeterli müzik aletlerinin sınıfta olmayıșı ve ayrı bir müzik odasının bulunmaması, okul öncesi öğretmenlerin müzik etkinliğini uygulamalarını diğer sorunlara göre daha fazla oranda etkilemektedir. Dere'nin (2008) yaptığı araştırmaya göre de öğretmenlerin \%55.66'sı sınıftaki çalgıların çocuk sayısına göre yeterli olmadı̆̆ını belirtmiștir. Öztürk'e (2007) göre, öğretmenin kullanacağı müzik aleti ve ritm araçları yeterli olmalıdır. Ayrıca okul öncesi eğitimde müzik eğitimi uygulamalarında uygulama yapılacak yerin yeterli olup olmaması, ayrı bir müzik odasının bulunup bulunmaması önemlidir (Öztürk, 2007: 90). Okul öncesi öğretmenlerin \%56.5 i, okul öncesi öğretmenlere yönelik okul öncesi eğitimde müzik öğretimi ile ilgili kurs veya hizmet içi eğitimin eksik olmasını müzik eğitimi uygulamaları ile ilgili yüksek bir oranda sorun olarak görmektedir. Bu bulgu, öğretmenlere yönelik müzik eğitimi ile ilgili hizmet içi eğitimin veya kursların yeterli olmadığı sonucunu ortaya çıkarmaktadır.

Yapılan bir araştırmada da (Dere, 2008) müzik eğitimi konusunda okul öncesi öğretmenlerin \%80.66’sının hizmet içi eğitime gereksinim duyduğu 
belirlenmiştir. Öğretmenler, çocukların ritim aletlerini kullanırken sürekli serbest şekilde kullanmayı istemelerini $\% 51.6$ oranla müzik etkinliği uygulamalarında sorun olarak göstermişlerdir. Elde edilen bu sonuç, çocukların müzik etkinliğinde ritim aletlerini kullanmayı tam olarak bilmedikleri veya öğretmenin çocuklara ritim aletlerinin nasıl kullanılacağ ile ilgili çocuklara rehberlik etme konusunda yeterli olmadığı şeklinde yorumlanabilir.

Tablo 10. Okul Öncesi Öğretmenlerinin “Aşă̆ldaki Seçenek/Seçeneklerden, Hangisi/Hangilerini Müzik Etkinliğinizi Uygulamada Sorun Olarak Görüyorsunuz?

(2. Bölüm)" Sorusuna İlişkin Dă̆ılımları

\begin{tabular}{|c|c|c|}
\hline $\begin{array}{l}\text { Așağıdaki Seçenek/Seçeneklerden } \\
\text { Hangisi/Hangilerini Müzik Etkinliğinizi } \\
\text { Uygulamada Sorun Olarak Görüyorsunuz? } \\
\text { (2. Bölüm) }\end{array}$ & $\mathbf{N}$ & $\%$ \\
\hline $\begin{array}{l}\text { Sınıfımdaki müzik aletleri kullanılamaz durumda (kırık, } \\
\text { bozuk vs.). }\end{array}$ & 11 & 17.7 \\
\hline $\begin{array}{l}\text { Çocukların aile yapıları veya okul dışı çevresi müzik } \\
\text { etkinliği uygulamalarına engel olabiliyor. }\end{array}$ & 11 & 17.7 \\
\hline $\begin{array}{l}\text { Şarkıları dinletirken çocuklar o sırada dans etmek } \\
\text { istiyorlar, şarkının söylenmesi engelleniyor. }\end{array}$ & 11 & 17.7 \\
\hline Ses sistemimiz/hoparlörümüz yok. & 10 & 16.1 \\
\hline Müzik setimiz yok. & 9 & 14.5 \\
\hline $\begin{array}{l}\text { Ritim aletlerinin kullanılabilecek durumda } \\
\text { olmamasından dolayı çocuklar etkinliğe katılmak } \\
\text { istemiyor. }\end{array}$ & 9 & 14.5 \\
\hline Müzik formasyonum eksik & 9 & 14.5 \\
\hline Çocuk şarkılarının melodilerini bilmiyorum. & 9 & 14.5 \\
\hline $\begin{array}{l}\text { Alışıldık konular (kahramanlık, doğa, okul gibi) müzik } \\
\text { etkinliğinde çoğunlukla kullanılıyor. }\end{array}$ & 8 & 12.9 \\
\hline Sinıf mevcudu kalabalık & 8 & 12.9 \\
\hline Disiplinler arası işbirliği yetersiz. & 7 & 11.3 \\
\hline Beste aşamasında kolaylık gözetilmiyor. & 7 & 11.3 \\
\hline $\begin{array}{l}\text { Çocuğun gelişim düzeyine uygun çocuk şarkıları } \\
\text { yetersiz. }\end{array}$ & 7 & 11.3 \\
\hline Elektronik bazı cihazlarımız var ama bozuk, çalışmıyor. & 7 & 11.3 \\
\hline Çocuklarda dinleme problemi var. & 7 & 11.3 \\
\hline 6 yaş ve öncesi çocuk ses aralığı yeterince gözetilmiyor. & 6 & 9.7 \\
\hline $\begin{array}{l}\text { Çocuk şarkılarını söylerken ritimlerde eksiklik } \\
\text { yaşıyorum. }\end{array}$ & 6 & 9.7 \\
\hline
\end{tabular}


Okul öncesi öğretmenleri müzik etkinliğini uygularken \%17.7'şer oranlarla sınıfindaki müzik aletlerinin kullanılamaz durumda (kırık, bozuk vs.) olmasını; çocukların aile yapıları veya okul dışı çevresinin müzik etkinliği uygulamalarına engel olmasını ve şarkıları dinletirken çocuklar o sırada dans etmek isteyerek şarkının söylenmesinin engellenmesinin sorun olduğunu ifade etmişlerdir. Okul öncesi öğretmenlerinin \%16,1'ine göre ses sistemi/hoparlör olmaması müzik etkinliği uygulamasında bir sorundur. Ayrıca okul öncesi öğretmenleri \%14.5 oranlarla müzik seti olmamasını, ritim aletlerinin kullanılabilecek durumda olmamasından dolayı çocukların etkinliğe katılmak istememesini ve öğretmenin müzik formasyonunu eksik görmesini müzik etkinliğini uygulamada sorun olarak görmektedir. Alışıldık konuların (kahramanlık, doğa, okul gibi) müzik etkinliğinde çoğunlukla kullanılmasinı ve sinıf mevcudunun kalabalık olmasinı \%12.9'ar oranlarla okul öncesi öğretmenleri müzik etkinliğini uygulamada sorun olarak gördügünü belirtmiştir. Okul öncesi öğretmenler \%11.3 oranlarla disiplinler arası işbirliği yetersiz olmasını; beste aşamasında kolaylık gözetilmemesini; çocuğun gelişim düzeyine uygun çocuk şarkıları yetersiz olmasını; elektronik bazı cihazların bozuk olup çalışmamasını ve çocuklarda dinleme probleminin olmasını müzik etkinliğini uygulamada sorun olarak görmektedirler. \%9.7'şer oranlarla okul öncesi öğretmenlerin müzik etkinliğini uygulamada karşılaştığ diğer sorunlar 6 yaş ve öncesi çocuk ses aralı̆̆ının yeterince gözetilmemesi ve çocuk şarkılarını söylerken ritimlerde eksiklik yaşamasıdır. 
Tablo 11. Okul Öncesi Öğretmenlerinin “Aşăgldaki Seçenek/Seçeneklerden, Hangisi/Hangilerini Müzik Etkinliğinizi Uygulamada Sorun Olarak Görüyorsunuz? (3. Bölüm)" Sorusuna İlişkin Dağılımları

\begin{tabular}{|c|c|c|}
\hline $\begin{array}{l}\text { Așağıdaki Seçenek/Seçeneklerden } \\
\text { Hangisi/Hangilerini Müzik Etkinliğinizi } \\
\text { Uygulamada Sorun Olarak Görüyorsunuz? } \\
\text { (3. Bölüm) }\end{array}$ & $\mathbf{N}$ & $\%$ \\
\hline $\begin{array}{l}\text { Başka sınıflardan müzik aleti, kitap, cd çalar vs. } \\
\text { temin etmek durumunda kalıyorum. }\end{array}$ & 5 & 8.1 \\
\hline Çocuklar tekrar etmede problem yaşıyorlar. & 5 & 8.1 \\
\hline Çocukların müziğe ilgisi yok ya da az düzeyde. & 4 & 6.5 \\
\hline Çocuklar müzik etkinliğine isteksiz yaklaşıyor. & 4 & 6.5 \\
\hline $\begin{array}{l}\text { Müzik etkinliği eğlence ve oyalanmaya yönelik } \\
\text { kullanılmasından kaynaklı olarak çocuk beklentisi } \\
\text { ve algısı yön değiştiriyor. }\end{array}$ & 4 & 6.5 \\
\hline $\begin{array}{l}\text { Kurumda müzik, eğitim aracı olarak } \\
\text { kullanılmıyor. }\end{array}$ & 4 & 6.5 \\
\hline Ritim aletlerine gereken önemi vermiyorum. & 4 & 6.5 \\
\hline $\begin{array}{l}\text { Müzik öğretmeninin sınıfta sürekli } \\
\text { bulunmamasından kaynaklı olarak çocuk müzik } \\
\text { öğretmenini ağabey, abla olarak görüyor. }\end{array}$ & 3 & 4.8 \\
\hline $\begin{array}{l}\text { Okul öncesi çocuğa müzik eğitimi verme } \\
\text { konusunda yetersizim. }\end{array}$ & 2 & 3.2 \\
\hline Müzik etkinliği konusunda isteksizim. & 2 & 3.2 \\
\hline $\begin{array}{l}\text { Çocuk şarkıları söyleme tarzım çocukların } \\
\text { dikkatini çekmiyor. }\end{array}$ & 2 & 3.2 \\
\hline $\begin{array}{l}\text { Şarkı öğretimi eğitimin bir parçası olarak } \\
\text { kullanılmıyor ve müzik dışlanıyor. }\end{array}$ & 2 & 3.2 \\
\hline $\begin{array}{l}\text { Kurumsallaşma problemi nedeniyle müzik } \\
\text { etkinliği sürekli yapılamıyor. }\end{array}$ & 1 & 1.6 \\
\hline $\begin{array}{l}\text { Öğreteceğim şarkıyı bir anda öğretmeye } \\
\text { çalışıyorum. }\end{array}$ & 1 & 1.6 \\
\hline Müzik duygusundan yoksunum. & 1 & 1.6 \\
\hline Mesleğini sevmiyorum. & 1 & 1.6 \\
\hline
\end{tabular}

Tablo 11 incelendiğinde; okul öncesi öğretmenlerinin \%8.1'er oranlarla başka sinıflardan müzik aleti, kitap, CD çalar vs. temin etmek durumunda kalmasının ve çocukların tekrar etmede problem yaşamasının; \%6.5'er oranlarla çocukların müziğe ilgisinin olmaması ya da az düzeyde olmasının, çocukların müzik etkinliğine isteksiz yaklaşmasının, müzik etkinliğinin 
eğlence ve oyalanmaya yönelik kullanılmasından kaynaklı olarak çocuk beklentisi ve algısının yön değiştirmesinin, kurumda müziğin eğitim aracı olarak kullanılmamasının ve ritim aletlerine gereken önemin verilmemesinin müzik etkinliğini uygulamada sorun olarak gördükleri görülmektedir. Okul öncesi öğretmenlerinin \%4.8'i müzik öğretmeninin sinıfta sürekli bulunmamasından kaynaklı olarak çocuğun müzik öğretmenini ağabey, abla olarak görmesini müzik etkinliğini uygulamada sorun olarak görmektedir. Ayrıca, \%3.2'şerlik oranlarla müzik etkinliğini uygulamada; okul öncesi çocuğa müzik eğitimi verme konusunda yetersiz olma, müzik etkinliği konusunda isteksiz olma, çocuk şarkıları söyleme tarzının çocukların dikkatini çekmemesi, şark1 öğretiminin eğitimin bir parçası olarak kullanılmaması ve müziğin dışlanması sorun olmaktadır. Kurumsallaşma problemi nedeniyle müzik etkinliğinin sürekli yapılamaması, öğretmenin öğreteceği şarkıyı bir anda öğretmeye çalışması, öğretmenin müzik duygusundan yoksun olması ve mesleğini sevmemesi \%1.6'şar oranlarla müzik etkinliğini uygulamada sorun olarak görülmektedir.

\section{Sonuç ve Öneriler}

Araştırma sonucunda, okul öncesi öğretmenlerinin \%66.1'nin müzik alanındaki yeterlilik düzeyine ilişkin karşılaştığı sorunlar olduğu belirlenmiştir. Okul öncesi öğretmenlerinin \%33.1'i müzik alanındaki yeterlilik düzeyine ilişkin sorun yaşamadığını belirtmiştir. Okul öncesi öğretmenlerin \%33.9'u, müzik alanındaki yeterlilik düzeyine ilişkin karşılaştığ1 sorunların kaynağ1 olarak enstrüman kullanmayı göstermişlerdir. Okul öncesi öğretmenleri \%58.1'i okul öncesi dönemde müzik etkinliği uygulamaları ile ilgili kişisel gelişimine katkıda bulunmak için çaba harcadığ1 belirtirken; \%30.6'sı bu konuda çaba harcamadığını belirtmiştir. Okul öncesi öğretmenlerinin \%87.1'inin müzik etkinliğini başka etkinliklerle bütünleştirdiği belirlenmiştir. Araştırmaya katılan okul öncesi öğretmenlerinin \%16.1'er oranlarda müzik etkinliğini, drama etkinliği ve fen etkinliği ile bütünleştirirken sorunla karşılaştıkları saptanmıştır. Müzik etkinliğinde aile katılım çalışmalarına yer verme açısından okul öncesi öğretmenlerinin \%46.8'inin aile katılım çalışmalarına yer verdiği, \%51.6'sının müzik etkinliğinde aile katılım çalışmalarına yer vermediğ bulunmuştur. Müzik etkinliğinde aile katılım çalışmalarında okul öncesi öğretmenlerinin \%33.9'u müzik etkinliği uygulamalarını evde çocukla birlikte aileleri ile uygulamaları konusunda sorun yaşamaktadır. Okul öncesi öğretmenlerinin müzik etkinliği uygulamalarında sınıf yönetimi konusunda karşılaştığ1 sorunlar incelendiğinde, \%33.9 oranla müzik etkinliğinde çocukların yaratıcılıklarını destekleyen ortam sağlayabilme ilk sırada yer almaktadır. Bu sırayı \%25.8 oranla müzik etkinliğinde ilgi ve güdünün sürekliliğini sağlayabilmenin takip ettiği belirlenmiştir. Okul öncesi 
öğretmenleri, \%62.9'ar oranlarla sınıftaki müzik aletlerinin sayısının yetersiz olmasını ve okulda bir müzik odasının olmamasını müzik etkinliğini uygulamada sorun olarak gördüklerini belirtmişlerdir. \%56.5'i okul öncesi öğretmenlere yönelik okul öncesi eğitimde müzik öğretimi ile ilgili kurs/hizmet içi eğitim eksikliğini; \%51.6's1 çocukların ritim aletlerini kullanırken sürekli serbest şekilde kullanmayı istemelerini; \%45.2'si çocukların aynı müzik aletini aynı anda istemesini; \%43.5'i çocukların ritim aletlerini kullanmayı bilmediklerinde farklı ritim tutmalarını, bu durumun karmaşa yaşanmasına neden olmasını; \%41.9'u çocukların ritim aletlerini kullanırken uyumsuz davranış göstermesini; \%40.3'ü şarkı dinlemek için CD olmamasını; \%38.7'si müzik etkinliği uygularken bazı çocuklar konuşarak diğer çocukların dikkatini dağıtmasını ve çocukların motivasyonlarının düşmesini; \%33.9'u okulda bir müzik öğretmeni olmamasını; \%29'u okul öncesi öğretmenliği lisans programlarında müzik öğretimine yeterince yer verilmemesini; \%27.4'ü sinıfta yardımc1 bir öğretmen bulunmamasını $\% 24.2$ 'şer oranlarla çocukların ritim aletlerini ritim duygusu içersinde kullanmamasını, çok çeşitte ritim aleti kullanıldığında çocukların ritim tutmakta zorlanmasını ve karşılaştı̆̆ ş̧arkılarda nota, vurgu ve vuruşları çıkaramamasını; \%22.6'sı çocukların bazılarının özgüven eksikliği yaşamasını; \%21'i sınıfında çeşitli müzik etkinliklerini uygulamak için alanın yetersiz olmasını; \%19.4 oranlarda ise sınıfında hiç müzik aleti bulunmamasını ve sınıfında bir müzik köşesi olmamasını müzik etkinliğini uygulamada sorun olarak gördügünü belirtmiştir. Kurumsallaşma problemi nedeniyle müzik etkinliğinin sürekli yapılamaması, öğretmenin öğreteceği şarkıyı bir anda öğretmeye çalışması, öğretmenin müzik duygusundan yoksun olması ve mesleğini sevmemesi \%1.6'şar oranlarla müzik etkinliğini uygulamada okul öncesi öğretmenler tarafindan en az sorun yaşanılan faktör olarak görülmektedir. Elde edilen bu bulgular doğrultusunda şu önerilerde bulunulabilir:

- Okul öncesi öğretmenleri müzik eğitimi uygulamaları ile ilgili kendi kişisel gelişimlerine katkıda bulunmak için müzik eğitimi kurslarına katılabilir, çocuklarla orff çalışmalarına yönelik eğitim alabilirler.

- Okul öncesi öğretmenleri müzik etkinliği uygulamalarında daha fazla aile katılım çalışmalarına yer verebilir.

- Aileler, okul öncesi eğitim kurumları tarafından çocuklarının müzik eğitimi ile ilgili bilgilendirilebilir.

- Okul yönetimi, anasınıflarında ve anaokullarında müzik aletlerinin yeterli duruma gelmesi için kaynak yaratabilir.

- Okul öncesi öğretmenlere yönelik müzik eğitimi uygulamaları ile ilgili hizmet içi eğitim ve kurslar düzenlenebilir. 
- Aynı araştırma farklı illerde daha büyük bir örneklem grup üzerinde yapilabilir.

- Planlanacak bașka bir araștırmada, okul öncesi dönemde müzik eğitimi ve yaratııılık arasındaki ilişki incelenebilir.

- Bundan sonra yapılacak bir araştırma, okul öncesi öğretmenlerinin diğer etkinliklerdeki yeterliliklerinin değerlendirilmesine yönelik planlanabilir.

\section{Kaynakça}

ARAL, Neriman, KANDIR, Adalet ve CAN YAŞAR, Münevver. (2002), Okul öncesi Eğitim ve Anasinıfi Programları, 1. Basım, İstanbul: Turan Ofset.

ARSLAN, Ayșen. (1999), "Çocukta Dil ve Müzikal Yeteneğin Gelişimi”, Marmara Üniversitesi Anaokulu Öğretmeni El Kitabı, 1. Basım, İstanbul: Ya-Pa Yayınlar1, ss. 137-142.

ARTAN, İsmihan. ve BAL, Servet. (1993), Okul Öncesi Dönemde Müziğin Gelişimi ve Etkinlik Örnekleri, 9. Okul Öncesi Eğitimi ve Yaygınlaştırılması Semineri. Ankara: Ya- Pa, ss. 235-249

ARTAN, İsmihan. (1994), Okul öncesi Dönemde Müzik Eğitimi ve Etkinlik Örnekleri”, Okul öncesi Eğitimcileri İçin El Kitabı, (Ed.) Şule Bilir, İstanbul: Ya-Pa Yayınlar1, ss. 103-116.

ARTAN, İsmihan. (2003), Okul öncesi Dönemde Işsitsel Algının Geliştirilmesi, Erken Çocuklukta Gelişim ve Eğitimde Yeni Yaklaşımlar, (Ed.), M. Sevinç, İstanbul: Morpa Kültür Yayınları, ss. 273-281.

AYVACI, Hakan Șevki., DEVECİĞLU, Yasemin. ve YİĞíT, Nevzat. (2002), Okul Öncesi Öğretmenlerinin Fen ve Doğa Etkinliklerindeki Yeterliliklerinin Belirlenmesi, http://www.fedu.metu.edu.tr/UFBMEK5/b_kitabi/PDF/OgretmenYetistirme/Bildiri/t277d.pdf Erişim Tarihi: 10.01 .2014

BAŞER, Fatma Adile. (2004), "Müziğin Okul Öncesi Dönemde Çocuk Gelişimine Katkısı”, Sakarya Üniversitesi Eğitim Fakültesi Dergisi, Vol. Güz, No. 8, Oct. 2004.

http://web.archive.org/web/20070717194221/http://www.ef.sakarya.edu .tr/dergi/efdergisayi8.pdf (25.05.2013).

BILHARTZ, Terry D., BRUHN, Rick A. and OLSON, Judith E. (1999), The Effect of Early Music Training on Child Cognitive Development, Journal of Applied Developmental Psychology, Vol. 20, No. 4, pp. 615-636. 
Büyüköztürk, Ş. (2010), Sosyal Bilimler İçin Veri Analizi El Kitabı. İstatistik, Araştırma Deseni SPSS Uygulamaları ve Yorum, 11. Bask1, Ankara: Pegem A Yayıncılık.

BÜYÜKÖZTÜRK, Şener., KILIÇ ÇAKMAK, Ebru., AKGÜN, Özcan Erkan., KARADENIZ, Şirin. ve DEMIREL, Funda. (2009), "Bilimsel Araştırma Yöntemleri”, (4. Baskı), Ankara: Pegem Yayınları.

DERE, Zeynep. (2008), Ankara Il Merkezindeki Anasinıflarında Görev Yapan Öğretmenlerin Müzik Ĕ̈itiminde Yaşadıkları Sorunların İncelenmesi, Gazi Üniversitesi Eğitim Bilimleri Enstitüsü, Yayınlanmamış Yüksek Lisans Tezi, Ankara.

ERKUNT, Nimet. (2000), Okul öncesi Eğitimi ile Illgili Uygulamalı Çalışmalar, İstanbul: Esin Yayınevi.

ESKİĞLU, Itır. (2005), Müzik Eğitiminin Çocuk Gelişimi Üzerine Etkileri, Cumhuriyetimizin 80. Yılında Müzik Sempozyumu, İnönü Üniversitesi, Malatya Bildiriler, ss. 116-123, 2003, http//www.muzik eğitimcileri.net/bilimsel/bildiri/Eskioğlu (25.05.2013).

GÜLER, Nilgün. (2006), Okul öncesi Öğretmenlerin Müzik Etkinliklerini Gerçekleştirme Durumları ve Eğitim Gereksinimlerinin Belirlenmesi, Anadolu Üniversitesi Eğitim Bilimleri Enstitüsü Yayınlanmamış Yüksek Lisans Tezi, Eskişehir.

GÜNGÖRMÜŞ ÖZKARDEŞ, Oya. (2005), Okul Öncesi Eğitim Kurumlarında Müziğin Kullanımı. Okul Öncesi Eğitimde Güncel Konular, (Ed.), Oktay, A., Unutkan, O. P., İstanbul: Morpa Yayınları. s. 266- 277.

HIRSH, Rea Ann. (2004), Early Childhood Curriculum, Incorporating Multiple Intelligences, Developmentally Appropriate Practice, and Play, Pittsburg Pennsylvania: Pearson, pp: 205- 207.

ISENBERG, J. P. and JALONGO, M. R. (1997), Creative Expressin and Play in Early Childhood, 2. Edition. New Jersey: Merrill Prentice Hall, pp: 131- 132.

MENTIŞ KÖKSOY, Aylin ve MENTIŞ TAŞ, Ayşe. (2005), "Okul öncesi Eğitim Kurumlarında Görev Yapan Anaokulu Öğretmenlerinin Okul öncesi Dönemde Müzik Eğitimine İlişsin Görüşlerinin Belirlenmesi”, Gazi Üniversitesi Kırşehir Eğitim Fakültesi Dergisi, Cilt 6, Say1 1, ss. 31-40.

MERTOĞLU, Ercan. (1993), "Okul öncesi Eğitimde Müziğin Gelişimi ve Eğitimi”, 9. Okul öncesi Eğitim ve Yaygınlaştırılması Semineri, İstanbul: Ya-Pa Yayınları, ss. 250-253.

MERTOĞLU, Ercan. (2005), "Okul Öncesi Dönemde Ritm Ĕ̈itimi”, Okul Öncesi Eğitimde Güncel Konular, (Ed.), Oktay, A. ve Unutkan, O. P., İstanbul: Morpa, ss. 281-301. 
MILLİ EĞİTiM BAKANLIĞI. 2006, Okul Öncesi Eğitim Kurumlar Yönetmeliği, Ankara: Milli Eğitim Basımevi.

OVERY, Katie., NORTON, Andrea., CRONIN, Karl., WINNER, Elen and SCHLAUG, Gottfried. (2005), "Examining Rhythm And Melody Processing in Young Children Using FMRI", New York Academy of Sciences, Vol. 1060, No. 1, pp: 210- 218.

ÖZAL GÖNCÜ, İlknur. (2002), 4-6 Yaş Anaokulu Çocuklarına Uygulanan Müzik Ĕgitiminin Müziksel Ses Ve İsitsel Algl Gelişimlerine Etkileri, Gazi Üniversitesi Fen Bilimleri Enstitüsü Yayınlanmamış Doktora Tezi, Ankara.

ÖZTÜRK, Ayten. (2007), Okul Öncesi Eğitimde Müzik, İstanbul: Morpa Yayınları.

POYRAZ, Hatice. (1998), Okul öncesi Faaliyetlerin Çocuğun Dil Gelişimine Etkileri, Marmara Üniversitesi Anaokulu/Anasınıfı Öğretmen E1 Kitab1, 1. Basım, İstanbul: Ya-Pa Yayınları, ss. 56-72.

RAUSCHER, Frances H., RAUSCHER, Frances H. (2003), Can Music Instruction Affect Children's Cognitive Development?, pp: 2- 3, ED4805402003-09-00.www.eric.ed.gov (09.09.2007).

SCHELLENBERG, E. Glenn. (2005), Music and Cognitive Abilities, American Psychological Society, Vol. 14, No. 6, pp. 317- 320.

SCHLAUG, Gottfried., NORTON, Andrea., OVERY, Kate and WINNER, Ellen. (2005), "Effects of Music Training on The Child's Brain and Cognitive Development", New York Academy of Sciences, Vol. 1060, No. 1, pp: 219- 230.

SIĞIRTMAÇ DİKİĊ, Ayperi. (2006), Okul Öncesi Öğretmenlerin Müzik Eğitimi Konusundaki Görüşleri ve Kendilerine Ait Değerlendirmeler, 15. Ulusal Eğitim Bilimleri Kongresi, Muğla: Muğla Üniversitesi, Eğitim Fakültesi.

TEMİ, Ebru. (2006), Okul Öncesi Dönemde Müzik Eğitimi; Yaşanan Problemler ve Çözüm Önerileri, Ulusal Müzik Eğitimi Sempozyumu, 26- 28 Nisan, Pamukkale Üniversitesi Eğitim Fakültesi, Denizli.

TSELENTIS, Colleen MclDonald. (2000), Effective Teaching Practices in A Preschool Music and Movement Program, An Observational Study, MS. Thesis, University of Arizona.

YAVUZER, Haluk. (2000), Bedensel Zihinsel ve Sosyal Gelişimi ile Çocuğunuzun İlk Altı Yılı, 12. Basım, İstanbul: Remzi Kitabevi. 